\title{
An Assessment of an Urban Development-Flood-Impact Relationship in a Near Millionaire City of Cameroon (Bamenda)
}

\author{
Zephania N. Fogwe \\ Department of Geography and Planning, Faculty of Arts, The University of Bamenda, Bamenda, Cameroon \\ Email:nfogwez@yahoo.co.uk
}

Received 24 December 2015; accepted 25 April 2016; published 28 April 2016

Copyright (C) 2016 by author and Scientific Research Publishing Inc.

This work is licensed under the Creative Commons Attribution International License (CC BY).

http://creativecommons.org/licenses/by/4.0/

(c) (i) Open Access

\begin{abstract}
Since the 1990s flood water hazards have recurrently created reason vexing moments on the Cameroonian urban folk of major and minor towns by inflicting fatality toll beating-off manned efforts to mitigate the ugliness unleashed. Flood catastrophe in frequency and toll in towns sited on more inland highland towns like Bamenda has given birth to dynamic survival strategies since impacts change in space and time. Northern Bamenda has emerged as haven for ravaging River Mezam with rising forms of flood havoc on humans and their investments. Primary and secondary data collected from related stakeholders (government and municipal officials concerned with abating the flood occurrence and managing its aftermath as well as individuals who consciously or not trigger the floods). The aim of this study was to relativize flood water bearing on urban population reactions in the wake of the rising calamity. Results reveal that flood trends are advancing yearly in the like of fatalities that systematically make nonsense of urban setup human endeavours to tame floods. This study considers that an urgent urban flood hazard perception revolution must be engaged for this unplanned urban front that is developing where the topography presents a funnelling effect to stream water and so obviously has no respect for the existing flood countering socio-economic and engineering adaptations. Such flood disrespect for urban humans call for man-centred innovative and comprehensive paradigms should there be any hope for less hazardous sustainable city growth in Cameroon.
\end{abstract}

\section{Keywords}

Bamenda, Flood, Fatalities, River Mezam, Stream, Population 


\section{Introduction}

Flood intensity has increased since the 1990s in coastal and inland towns where river ad stream banks dry up in the dry season so that infrastructure is implanted on the flood plains. In the flood plains of Bamenda numerous land reclamation activities take place especially at Nkwen that is lowland. The floodplain topography is generally a low lying plain which makes construction of houses relatively easy. This is practised Below Foncha extending to Mulang with many houses occupied by the rich have been fenced with stones and concrete embankments to prevent floods yet the floods are recurrent in down town Bamenda at Nkwen, Post Office Mankon, Mbengwi Park, Mile Four Nkwen, Miss Ngeng Junction, Cow Street, La Chance, Old Town, Below Foncha, Sisia and Mulang. Material and human damages thereof portray enormous and countless structural and nonstructural measures at individual and collective level. These impact urban dwellers irrespective of whether private and public sector partners with the same or even greater fatality toll. The measures implemented appear to yield only limited success not just in space but time. This study analyses flood impact and how private and public stakeholders have held strong to set up repeatedly defeated counter flood measures and suggests the need for a more sustainable approach to this urban recurrent floods in Cameroon [1] that are issuant of water response and population counteractions mismatch paradigms based on the Bamenda example.

\section{Methodology}

This work focused on describing and analysing flood trends, magnitude with emphasis on the effects and failed countering measures. Descriptive statistical data collection methods were used to ascertain the flood triggers through a random sampling and stratified random sampling techniques in which some 192 questionnaires were administered on highly vulnerable stakeholders. Primary data was obtained through field observations, structured questionnaire and personal/group interview from June to October 2014. Interviews with resource persons in Sisia, Ndamukong, Ntasen, Ngomgham, Mulang, Ntankah and Ndamukong were based on flood perception. Secondary data from published and unpublished materials was also collected and treated qualitatively and quantitatively.

\section{Results and Discussion}

\subsection{Flood Hazard Evolution from Problem to Crises in Northern Bamenda}

Urban floods have marked the Mulang-Musang-Lower Foncha depression with a growing population provided with social facility like water, roads and electricity and most especially sensitisation to prevent encroachment with "NO LAND RECLAMATION" bill boards. The preservation philosophy underlying such boards was that earmarked areas had to serve as ecological niches and sponge out flood events. Initially the small urban population complied with the rigorously implemented urban management policy that allowed excess overland flow water to naturally collect itself off through these upper River Mezam tributaries. Early flood phenomena that appeared tameable and manageable was only sporadic and casualty was insignificant tangible non-economic losses. This lasted for only the economic crises years that had withheld infrastructural sprawl.

The regain of the economy and increasing economic prosperity there emerged a profound dynamism of the formal and informal economic sector which directly and indirectly pulled in a large labour force from the hinterlands and other regions. Dwelling space for new comers could only be found in the north of Bamenda (constrained by the Bamenda Station escarpment in the South, Mezam River by the West and the largely reserved public land towards Nkwen in the East). This increased the population (Table 1).

The long population growth at between $7 \%$ to $9 \%$ per year is more of migration than natural increase. The in-migrants squeezed into this basin for effective conquering of marshy swamps buttressed by a feeling of historical security against floods within constant rainfall trends. Indicators of such security perception were the infrastructural structures as houses, bridges and roads, as well as crop cultivation, ruminant livestock rearing and poultry activities. Rising urbanisation in the watersheds of the south reduced the lag time of the urban rain storms thus triggering the recurrent floods in this basin that an influx population had mistaken for a home.

The sense of home permitted the population to erect bridges with central pillars that enhance water blockage, planting eucalyptus trees to dry off the wetland at Ntankah which traps garbage and diverts water into neighbourhoods. Such water sporadically swept away houses, submerged agricultural land and carried away human beings with more than 10 deaths between 2005-2014. There has been increased reclamation (despite the "no 
Table 1. Population growth characteristics in Bamenda.

\begin{tabular}{ccccc}
\hline Year & Population & General increase & Percentage increase & Annual increase \\
1953 & 9765 & - & - & - \\
1964 & 18,489 & 8734 & 98.3 & 8.1 \\
1965 & 19,000 & 1489 & 2.2 & 2.8 \\
1968 & 25,900 & 6900 & 36.3 & 12.1 \\
1970 & 33,376 & 7476 & 28.9 & 14.1 \\
1976 & 44,764 & 11,388 & 34.1 & 5.1 \\
1987 & 203,480 & 150,943 & 287.3 & 35.9 \\
1992 & 257,200 & 53,720 & 26.4 & 5.3 \\
1993 & 270,000 & 13,200 & 5.1 & 5.1 \\
2005 & 427,149 & 156,749 & 59.9 & 4.8 \\
2015 & 907,766 & 480,617 & 112.5 & 11.2 \\
\hline
\end{tabular}

Source: Bamenda city council report, 2015.

land reclamation, by Bamenda City Council (BCC)” between Mulang bridge and Foncha Street Nkwen (Table 2).

Contributing activities are those of artisanal fishing that uses varied material to barrier the channel create ponds before fish using nets, hooks and baskets to fish out tilapia and mud fish. This makes the BCC unable to efficiently implement State legislation on constructional standards within the flood plain. The municipal authorities estimate that about $40 \%$ of the population lives out of the urban planning and housing regulations [2]. The progress of flood from problem to crises is indicative that contemporary rapid urban misplaced priorities are gaining grounds on indecorous ground. Upstream NO RECLAMATION and protected areas are increasingly reversed into topographic highs where structural lows existed. Shared out flood waters are increasingly squeezed unto this single depression that solely bears the tragedy of commons.

\subsection{A Flood Enhancing Environment and Contemporary Pattern in Northern Bamenda}

The River Mezam floodplains [3] within Bamenda align streams in Nkwen and Mankon collecting tributaries like Mughoro, Mugheb, Ayaba, Naaka, Ngengnwi, and La Chance from the Bamenda escarpment (Figure 1).

This pattern if maintained by a mean annual rainfall ranges between 1700 - $2824 \mathrm{~mm}$ (Figure 2).

Rainfall dropped from 2005 to 2007 with a slight increase from 2007 to 2009 then from 2011 there was a sharp drop to 2013, then a rise to 2014. This exposes the areas to the north of the town to floods where the altitudinal range is less than $1200 \mathrm{~m}$ and the topography is flat. This zone corresponds to the Ngomham-Mulang and Below Foncha depression highly exploited for market gardening of cabbages, tomatoes, vegetables, maize and colocassia for local consumption and sale in markets like Nkwen, Ntarikon, Main Market and Food Market. Maize, cocoyam and vegetables are grown in large quantities across the floodplain following seasonal changes in rainfall. This area has an extensive and effective urban flood land within a vast swamp (Figure 3).

Figure 3 shows that effective urban floods and not just swamps extend to Sisia, Bayelle, Cow Street, Ndamukong, Mulang, Below Foncha, Ntankah, Ngomgham and Latitah though in 2015 floods have reduced upstream in Sisia, Bayelle and Cow Street as a result of anti-flood adaptations like embankments in Sisia, raising up of foundations, demolishing and restructuring houses which are close to the stream channel and channel widening and straightening below Cow Street and Bayelle.

Conversely, floods have awfully increased downstream at Ndamukong Mulang, Ngomgham, Below Foncha, Ntankah and Latitah perhaps due the sudden increase in annual rainfall from $2550 \mathrm{~mm}$ in 2009 to $3267 \mathrm{~mm}$ in 2014 (Figure 2). This is a flow culmination point for many streams with broad narrow channels at Ntasen and Ngomgham which slows the flow speed and increased deposition on the bed [4]. Waste is trapped by vegetation thus replaces the water and ejects it over the banks Below Foncha and Ndamukong especially where people have constructed houses at Ndamukong reducing and narrowing the channel (Table 3). 
Table 2. Relative areas reclaimed in flood plains of northern Bamenda by 2015.

\begin{tabular}{ccc}
\hline Quarters & Flood plain area $\left(\mathbf{K m}^{2}\right)$ & Reclaimed area $\left(\mathbf{K m}^{2}\right)$ \\
\hline Below Foncha-Ntasin & 350 & 200 \\
Mulang-Ntasin & 450 & 75 \\
Mile 4-GTHS Nkwen & 1500 & 600 \\
Ngomgham & 552 & 42 \\
Total & 2852 & 917 \\
\hline
\end{tabular}

Source: Bamenda city council, 2015.

Table 3. Flood impact in Ndamukong from 2005 to 2014.

\begin{tabular}{ccc}
\hline Years & Flood water height (in meters) & Assessment of destruction (FCFA) \\
\hline 2005 & 40 & 700,000 \\
2006 & 30 & 650,000 \\
2007 & 40 & 800,000 \\
2008 & 45 & 865,000 \\
2009 & 30 & 800,000 \\
2010 & 50 & 900,000 \\
2011 & 60 & 962,000 \\
2012 & 62 & $1,000,000$ \\
2013 & 70 & $1,010,000$ \\
2014 & 80 & $1,150,000$ \\
\hline
\end{tabular}

Source: Fieldwork (2014).

The flood trends observed downstream Ndamukong were same in other parts of Bamendaaround the bridge leading to Mile Four Nkwen and Ntahtru, Below Mbengwi Park (Figure 4).

Flood water triggered destruction has increased be it at Ndamukong or Below Foncha at Mulang, Ntankah and Ngomgham. Between the years 2005 and 2014, some 453 houses have been affected (Table 4).

Flood impact is varied ranging from simple to situations where houses permanently abandoned by the occupant as Below Foncha and Ndamukong with the lateral extension of flood water reach 10 to 15 meters affecting houses constructed since 1990 while flood effects on houses started in 2003. Field observation Below Foncha show that some of the houses have been completely washed away without traces. Between May and July floods are more extensive reaching 30 to 50 meters from the banks (Figure 5).

Some houses were recently abandoned by the occupants. In July, August, and September to early October when flood water heights reach 60 meters the destruction is catastrophic taking away lives, rendering people homeless and taking away a lot of property. The occurrence and impact varies in time and space (Table 5). A count of some 375 houses were threatened including houses as far away as 70 meters from the stream in 2014.

Table 4 shows a dominance of flood frequency both downstream and in the third annual quarter (with more than half of all floods. The skewness of the occurrence downstream indicates that there exist unequal flood triggers with season.

\subsection{Wet Season Urban Flood Triggers in Northern Bamenda}

Uncontrolled dumping of waste materials into stream channel was observed to be the most severe trigger. Garbage collection services are offered by the BCC as using waste cans were provided by Dordrecht Council in Germany. Most urban dwellers in this northern zone choose to empty their garbage into nearby stream courses because for fear of over accumulation as BCC van hardly access the zone. Even garage owners along this river channel at Cow Street do same. The BCC indicates that 20 percent of the urban the population breach urban 


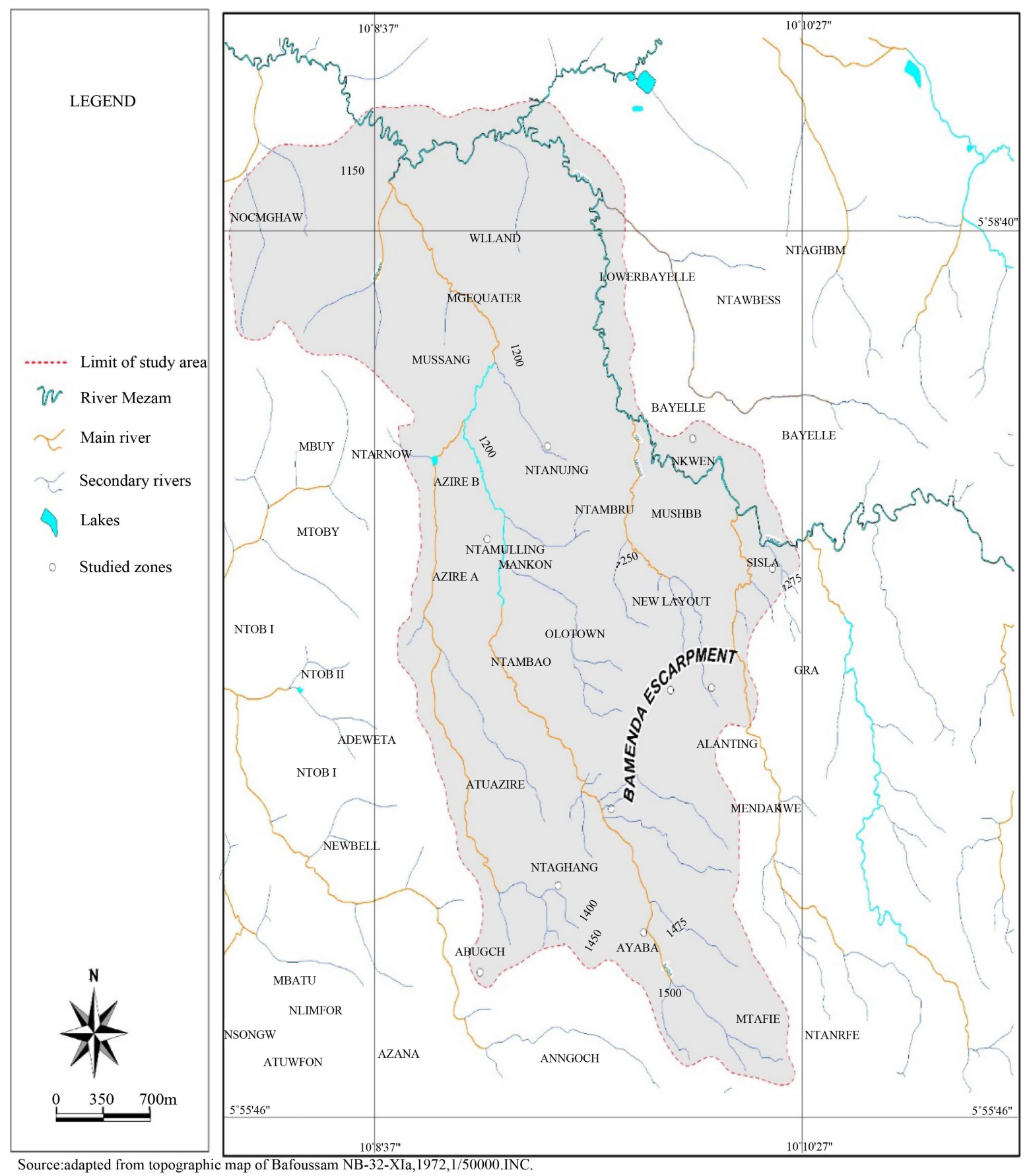

Figure 1. Map of the drainage pattern of Bamenda.

planning and housing regulations by dumping garbage into streams. Even with functional BCC waste collection system in some quarters, a good number of urban dwellers still deliberately dump their waste into gutters, road junctions and stream channels to constitute obstacles to flow as along many portions of the stream course in Mulang, Ndamukong and Below Foncha.

The rapid and unplanned growth of Bamenda urban space in the upstream of the channel ways has repercussions through the clearing of forest construction (earth works, transport roads, houses, pavements and pathways) which change drainage patterns, channelling of streams segments, construction of culverts and bridges [5]. This has effects on runoff volume, higher peak discharge and shorter time of concentration in July, August and 


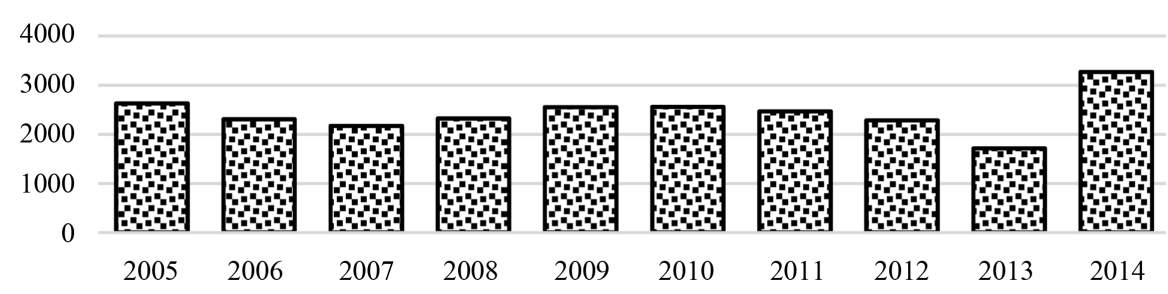

Figure 2. Mean annual rainfall from 2005-2014 for Bamenda.

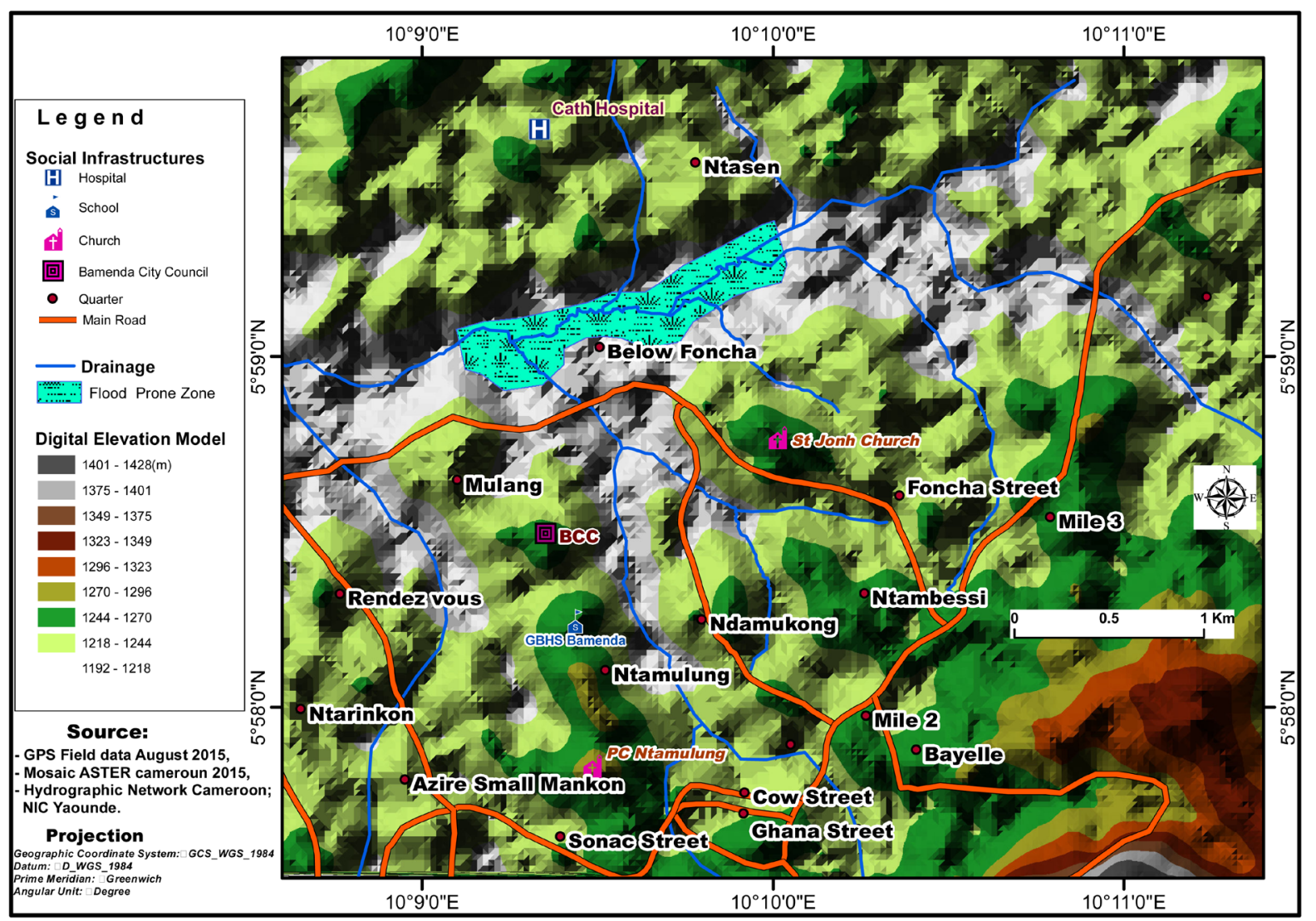

Figure 3. Digital terrain model of the flood prone area of northern Bamenda, 2015.

September as level of channel water overflows its banks. This was confirmed [6] [7] to have resulted from an increase in the rate at which surfaces are being paved, new houses constructed, dumping of waste materials into stream channels distorted and reduced in width which is as a result of urbanization.

\subsection{Prominence in Tangible versus Intangible Flood Losses in Bamenda in Recent Decades}

Field observations and data from the BCC revealed that 453 houses were affected by floods in the area covered by the satellite image (Figure 3) where flood water inflicted damage to computers, books, machines, vehicles with an overwhelming majority of houses affected (Table 6).

Field observations were systematically conducted in 2014using respondents at Below Foncha and Mulung. Over $91 \%$ of respondents acknowledged that floods have caused serious damage to houses and property as the situation was monitored before and after the flood event (Figure 6).

Such floods have created silent urban settlement refugees for fear of death though some still buy land and deploy various measures to harness them in contravention of Law No. 2004/003 organising town planning in 


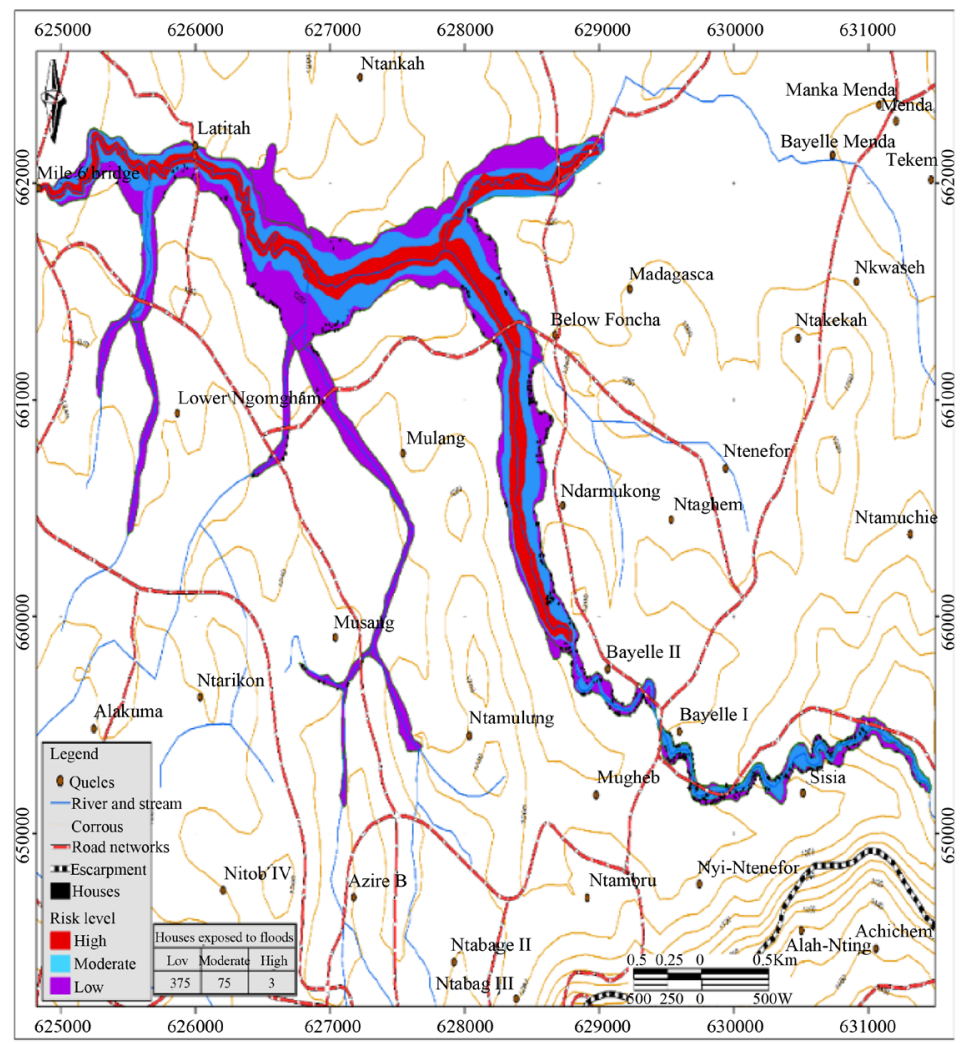

Soure:Landsat Image 2014 Compiled by CAMGIS

Figure 4. Flood levels and houses at risk.

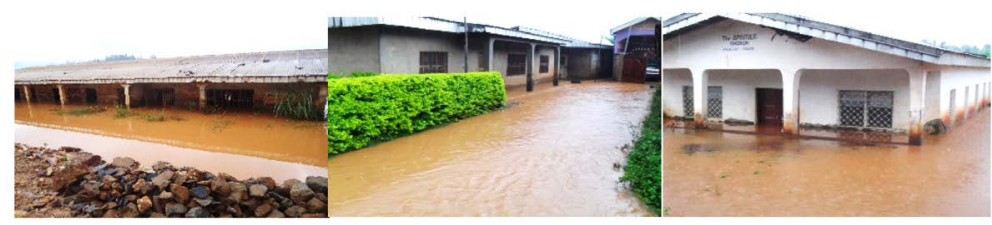

Figure 5. Houses affected by floods at below Foncha and Ndamukong. Source: Fieldwork 08/09/2014.
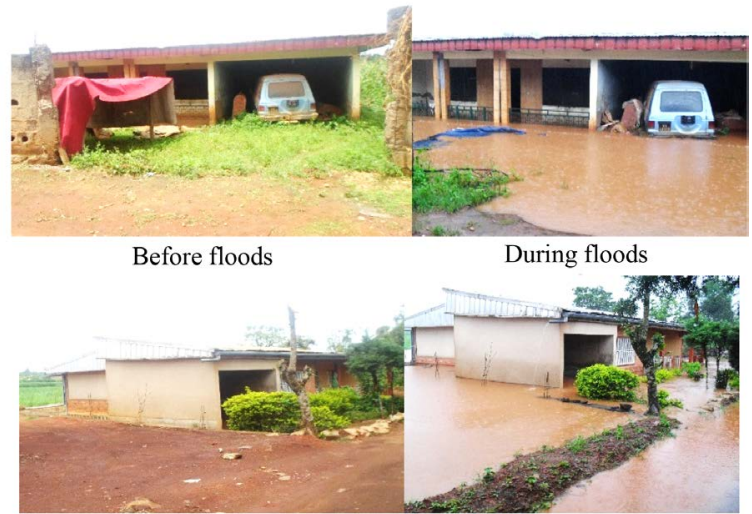

Before floods (27/03/14) During floods (08/09/2014)

Figure 6. Flood water level variation before and after the event Below Foncha. 
Table 4. Trends of flood causality and mitigation in Bamenda.

\begin{tabular}{|c|c|c|c|c|}
\hline $\begin{array}{l}\text { Decade flood } \\
\text { trend }\end{array}$ & Urban zone & Trigger factor & Target suggestion & Objective \\
\hline Regression & $\begin{array}{l}\text { Ntambag (Waterside towards } \\
\text { Old Town), Atuazire, Cow } \\
\text { Street, Nitop Four, Food } \\
\text { market, Ntenefor, Bayelle } \\
\text { Menda (bridge to Mile Four } \\
\text { Nkwen), Ntahtru (below } \\
\text { Mbengwi Park), Sisia }\end{array}$ & $\begin{array}{l}\text {-Channel straightening } \\
\text {-Channel widening } \\
\text {-Raising of foundations } \\
\text {-Embankments on the stream } \\
\text { channel }\end{array}$ & $\begin{array}{l}\text {-Demolish stream } \\
\text { channels bank houses } \\
\text {-Bridges to be raised } \\
\text {-Constant cleaning of the } \\
\text { stream channels by the } \\
\text { population }\end{array}$ & $\begin{array}{c}\text { Allow free } \\
\text { movement of } \\
\text { water }\end{array}$ \\
\hline Progression & $\begin{array}{l}\text { Ngie Quarter, La Chance, } \\
\text { Ngomgham } \\
\text { Mulang, Ngomgham, } \\
\text { Ndamukong }\end{array}$ & $\begin{array}{l}\text {-Houses constructed on river } \\
\text { channel } \\
\text {-The presence of vegetation on the } \\
\text { river channel which helps to trap } \\
\text { dirt of all types causing floods } \\
\text {-Little flood adaptation measures } \\
\text { put in place } \\
\text {-Low bridges }\end{array}$ & $\begin{array}{l}\text { - Houses on the stream } \\
\text { channels have to be } \\
\text { completely destroyed } \\
\text {-Bridges to be raised } \\
\text {-Constant dredging of } \\
\text { stream channels by the } \\
\text { BCC }\end{array}$ & $\begin{array}{c}\text { Increase } \\
\text { stream flow } \\
\text { speed }\end{array}$ \\
\hline
\end{tabular}

Source: Field work (2014).

Table 5. Spatial flood occurrence intensity calendar for Bamenda in the year 2014.

\begin{tabular}{ccccc}
\hline \multirow{2}{*}{ Urban space } & January to March & April to June & July to September & October to December \\
\cline { 2 - 5 } & Late dry season & Early rainy season & Late rainy season & Early dry season \\
\hline Sisia & 0 & 0 & 14 & 6 \\
Cow Street & 0 & 0 & 11 & 6 \\
Ndamukong & 0 & 10 & 10 & 8 \\
Latita & 0 & 1 & 11 & 2 \\
Ngomgham & 0 & 2 & 12 & 3 \\
Ntasen & 0 & 9 & 10 & 9 \\
Below Foncha & 0 & 11 & 20 & 9 \\
Mulang & 0 & 5 & $\mathbf{1 0 3}$ & $\mathbf{5 1}$ \\
Total & $\mathbf{0}$ & $\mathbf{3 8}$ & $\mathbf{5 3 . 6 5 \%}$ & $\mathbf{2 6 . 5 6 \%}$ \\
Percentage & $\mathbf{0 0}$ & $\mathbf{1 9 . 7 8 \%}$ & & 8 \\
\hline
\end{tabular}

Source: Fieldwork, November 2014.

Table 6. Relative flood effect perception on houses in northern Bamenda in 2014.

\begin{tabular}{|c|c|c|c|}
\hline Quarters & Respondents & Some effect & No effect \\
\hline Sisia & 20 & 18 & 2 \\
\hline Cow street & 19 & 14 & 5 \\
\hline Ndamukong & 26 & 26 & 0 \\
\hline Latita & 20 & 18 & 2 \\
\hline Ngomgham & 16 & 15 & 1 \\
\hline Ntasen & 22 & 17 & 5 \\
\hline Below Foncha & 35 & 35 & 0 \\
\hline Mulang & 34 & 32 & 2 \\
\hline \multirow[t]{2}{*}{ Total } & 192 & 175 & 17 \\
\hline & & $91.1 \%$ & $08.9 \%$ \\
\hline
\end{tabular}

Source: Fieldwork, 2014. 
Cameroon [8]. Most of them want to remain close as possible to the city so in some areas walls of houses were seriously affected and needed to be raised. Some toilet foundations are raised to avoid they do not sink (Figure 7).

Urban mobility was hampered by the 27 July 2014 flood at the bridge Below Foncha and Ntankah that cut off traffic for 2 hours. Urban inhabitants put in place wooden causeway passage options and fobid heavy duty vehicles from using the road. Destruction of agricultural land and crops cultivated along river banks was observed in Latita, Ndamukong, and Below Foncha.

Post flood events left standing water behind most houses in Mulang and Below Foncha creating conducivebreeding environments for mosquitoes as vectors of malaria. The material losses were evaluated fieldwork and results were spatially significant and uneven (Figure 8).

This casualty figure was significantly similar to the awesome flood disaster in August 2015 hit hard with heavy toll Below Foncha (Table 7).

\subsection{Living-with-Flood Swamp Dweller Culture despite Failed Flood Taming Schemes in Bamenda}

There is a noticeable urban defiance of systematized land reclamation in the contemporary history of Bamenda.
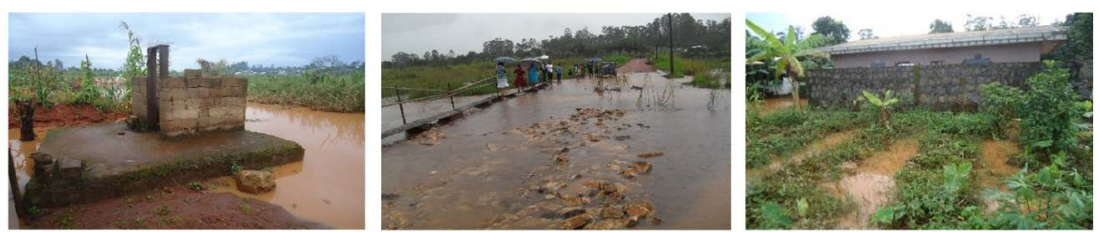

Figure 7. Sinking toilet, disruption of transport at Ntankah, flood of crop land.

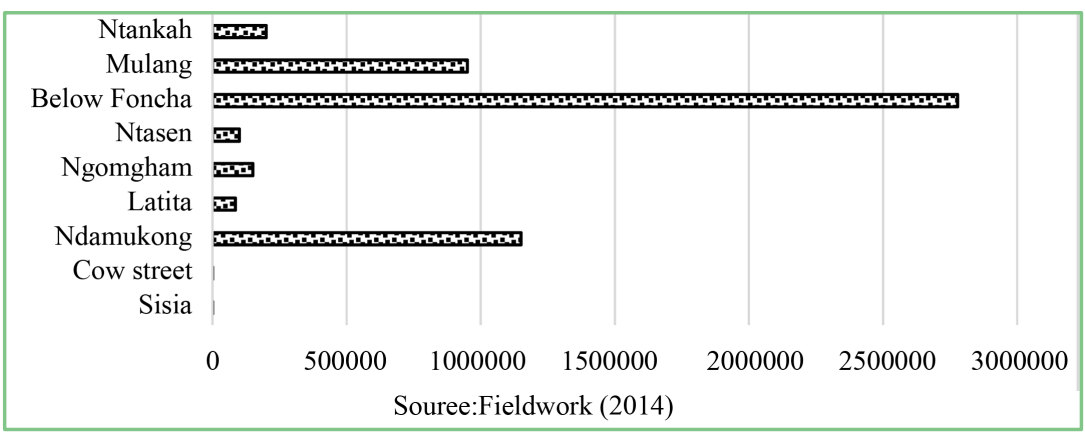

Figure 8. Financial losses from flood areas of Bamenda in 2014.

Table 7. Havoc inflicted by the ravaging August 2015 flood Below Foncha in Bamenda.

\begin{tabular}{|c|c|c|c|c|c|c|}
\hline \multirow[b]{2}{*}{ Quarters affected } & \multicolumn{4}{|c|}{ Total fatalities } & \multirow{2}{*}{$\begin{array}{c}\text { Other } \\
\text { material } \\
\text { damage }\end{array}$} & \multirow{2}{*}{$\begin{array}{c}\text { Estimated } \\
\text { financial loss }\end{array}$} \\
\hline & $\begin{array}{l}\text { Houses } \\
\text { affected }\end{array}$ & $\begin{array}{c}\text { Houses } \\
\text { submerged }\end{array}$ & $\begin{array}{c}\text { People } \\
\text { displaced }\end{array}$ & Animals killed & & \\
\hline Below Foncha & 20 & 06 & 16 & 45 chickens & & \\
\hline Ntasin & 16 & 04 & 06 & 10 chickens & & \\
\hline Mulang & 10 & 04 & 20 & $\begin{array}{c}100 \text { chickens } \\
06 \text { goats } \\
04 \text { pigs } \\
155 \text { chickens }\end{array}$ & $\begin{array}{l}\text { Documents } \\
\text { Electronic } \\
\text { equipment } \\
\text { Household } \\
\text { equipment, } \\
\text { vehicle }\end{array}$ & $\begin{array}{l}3.5 \text { million } \\
\text { FCFA }\end{array}$ \\
\hline Total & 46 & 14 & 42 & $\begin{array}{l}06 \text { goats } \\
04 \text { pigs }\end{array}$ & & \\
\hline
\end{tabular}


Reclamation earth is trucked in from afar in the dry season Below Foncha and Ntankah in loathe to "NO LAND RECLAMATION" sign post by the BCCin application of Law No 96/12 of 5 August 1996 relating to Environmental Management [9] and Ordinance No 74-1 for July 1974 fixing Rules on Land Tenure in Cameroon.

Channel manipulation by human engineering of essential characteristics was another thought out flood preventive measure believed to enhance the free flow of flood water and to minimize the destruction caused by floods (Figure 9).

It was equally observed that some foundations and court yards of houses were excessively raised above flood levels like in Sisia where they attained 3m height. There were many other strategies used to counter floods in Bamenda (Table 8).

\section{Conclusions}

From 2005 to 2014 considered in this study, floods have occurred several times in Bamenda with highest frequency and impact especially in August and September, at which time the destruction on lives and property were highest. The impact also caused abandonment of houses, disruption of transport, public and commercial services, financial loss as well as destruction of farmland and spread of diseases. Urban inhabitants along River Mezam tributaries in Bamenda and those who occupy the flood plains have put in numerous but failed strategies to combat the flood hazard situation, with most constructing embankments, raising foundations, doing channel widening and land reclamation. However, this has not really proven to be successful and unsustainable. Mindful of the various ramifications of floods, it is necessary to assess whether the anti-flood practices, policies or trends in Bamenda are moving towards or against urban planning sustainability. Mindful of this challenge, this study posits for a four-fold managerial sustainability. An economic sustainability with the capacity and ability of this flood plain land use practices to put resources to productive use for the long-term benefit of the Bamneda town in general and the Below Foncha community. It can be done without harming or depleting the natural resource

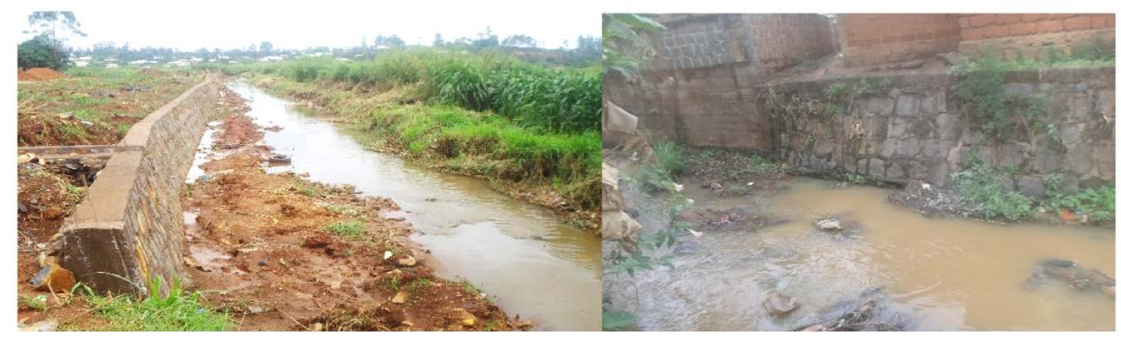

Figure 9. Channel straightening and embankment. Source: Fieldwork, 03/27/2015.

Table 8. Flood management strategies along River Mezam.

\begin{tabular}{|c|c|c|c|}
\hline Flood area & Flood Management Strategy & $\begin{array}{l}\text { Flood channel action } \\
\text { by population }\end{array}$ & $\begin{array}{l}\text { Expected flood reduction } \\
\text { response }\end{array}$ \\
\hline Below Foncha & Channel Widening & Width is increased & Can contain more water \\
\hline Below Foncha, Ntankah & Channel Deepening & Depth are increased & Reduced over flow \\
\hline Ndamukong, Mulang & Channel Straightening & Straightened and steepened. & Increased flow velocity \\
\hline $\begin{array}{c}\text { Sisia, Below Foncha, Cow } \\
\text { Street }\end{array}$ & Construction of embankments & $\begin{array}{l}\text { Build protective walls } \\
\text { with stone }\end{array}$ & Reduce lateral diversion \\
\hline Sisia, Ndamukong, Cow Street & $\begin{array}{l}\text { Raising the foundations and } \\
\text { verandas of houses above } \\
\text { flood levels }\end{array}$ & $\begin{array}{l}\text { Construction of the foundation } \\
\text { and court yards of houses }\end{array}$ & $\begin{array}{l}\text { Leave flood water at low } \\
\text { levels }\end{array}$ \\
\hline Ntankah, Ndamukong & Clearing of rivers and streams & $\begin{array}{l}\text { Removal of obstructions like } \\
\text { solid waste }\end{array}$ & Increased flow velocity \\
\hline $\begin{array}{l}\text { Latitah, Mile Six Mankon, } \\
\text { Ntankah }\end{array}$ & The raising of bridges & $\begin{array}{l}\text { Construction of bridges across } \\
\text { water courses to a certain height }\end{array}$ & $\begin{array}{l}\text { Withstand the passage of } \\
\text { waste materials under } \\
\text { them. }\end{array}$ \\
\hline
\end{tabular}

Fieldwork, 2014. 
base on which it depends. This would imply that the full impact of the flood recurrence is taken in view. Another variant is the social sustainability embodying fairness, inclusiveness and cultural adequacy of an intervention to promote equal rights over the natural, physical and economic capital that supports the livelihoods and lives of local communities, with particular emphasis on the poor and traditionally marginalised groups that inhabit most of northern Bamenda. An ecological sustainability would foster urban production and consumption on the integrity and health of the city urban infrastructures for "all" city dwellers without damaging or disrupting the urban region environment. Above all political sustainability to guarantee quality of governance systems guiding the relationship and actions of different actors among the previous four dimensions. Thereby, it implies the democratisation and participation of local civil society in all areas of decision-making.

In sum, urban governance stakeholders should draw up flood prevention/emergency plans that englobes all the facets of the flood triggers for there is every indication that these floods have come to stay so urgent and palliative alternatives become an absolute emergency. Very concretely, this study would suggest, what is most pragmatic for this flood hazard debacle:

- The inhabitants be teamed up into urban quarter sectorial dredging and opening up water courses in the sectors of the stream course within the Mezam drainage basin that are flood prone.

- A comprehensive master plan and structural plans be drawn to show green areas, agriculture and ensure the plan specifications are strictly observed. In this master plan the floodplains of Mezam and its tributaries should be mapped and preserved as green areas where no building and construction takes place there, even in the upper part of its slopes at the Station Hill.

- A detailed and clear demarcation is carried out accompanied by the mapping of flood risk zones risks zone in Bamenda, so that planners could give recommendations that match each risk level.

- There should be formal prohibition of the issuance of land titles and building permits within flood prone zones, no matter the circumstances.

\section{References}

[1] Fogwe, Z.N. (2008) Cameroon City Counter Flood Strategies. Journal of Applied Social Sciences, 7, 129-141.

[2] Ndenecho, E.N. (2010) Environmental Consequences of Rapid Urbanisation: Bamenda City, Cameroon. Journal of Environmental Protection, 1, 15-23. http://dx.doi.org/10.4236/jep.2010.11003

[3] Achu Fokam, R. (2011) Flood Risks and Adaptation Strategies on the Flood Plains of River Mezam in the Bafut Valley. A Dissertation Submitted in Partial Fulfilment of the Requirement for the Award of a Post Graduate Diploma (DIPES II) in Geography. ENS Yaounde, University of Yaounde 1

[4] Ndenecho, E.N., et al. (2005) Implication of Rapid Urbanisation for Flood Sediment and Debris Flow Hazard in Bamenda in Ecology and Natural Resource Development in the Western Highlands. Agwecam, Bamenda.

[5] Ward, R. (1978) Floods: Geographical Perspectives. Macmillan, London.

[6] Nyambod, E.M. (2010) Geographic Information Systems as a Tool for Participatory Land Administration in Bamenda City, North West Region Cameroon. University of Brussels, Brussels.

[7] Nyambod, E.M. (2010) Environmental Consequences of Rapid Urbanisation: Bamenda City, Cameroon. Journal of Environmental Protection, 1, 15-23. http://dx.doi.org/10.4236/jep.2010.11003

[8] Kometa, S.S. and Ndi, R.A (2012) The Hydro-Geomorphological Implications of Urbanisation in Bamenda, Cameroon. Canadian Center of Science and Education.

[9] Mbah, E.T. (2010) Flood Risks and Disaster Management Strategies in Bamenda Town. A Dissertation submitted in partial fulfilment of the requirement for the award of a post Graduate Diploma (DIPES II) in Geography. ENS Yaounde, University of Yaounde 1. 